\title{
Hydrogel Activity Test from Kirinyu Leaf Ethanol Extract (Chromolaena odorata (L.) R. King \& H. Rob) and Combination of Kirinyu Leaf Ethanol Extract with Collagen as a Healing Wound Excision.
}

\section{Thursina C. S. *, Reveny J, Sumaiyah S.}

Department of Pharmaceutical Technology, Faculty of Pharmacy, Universitas Sumatera Utara, Medan, Indonesia.

\begin{abstract}
A B S T R A C T
Objective: The purpose of this study was to determine the activity of the kirinyu leaf ethanol extract hydrogel preparation and the combination of the kirinyu leaf ethanol extract with collagen as a healing wound excision.

Method: This research is experimental, where the ethanol extracts of Kirinyu leaves and collagen are formulated in the form of hydrogel preparations and tested on the healing of excision wounds in rats. Testing wound healing activities were divided into 6 groups. The Group 1 (negative control) were given hydrogel base without Kirinyu leaf ethanol extract in combination with collagen, group 2 (positive control) were given Octenilin ${ }^{\circledR}$ gel, groups 3 and 4 , were given hydrogel of Kirinyu leaf ethanol extract while groups 5 and 6 were given hydrogel extract of kirinyu leaves combined with collagen.

Result: The results of percent reduction in wound diameter showed that groups 3 and 4 gave significant differences compared to group 1 which began to be seen on the 10th day $(\mathrm{p}<0.05)$. While groups 5 and 6 gave significant differences that began to be seen on the 8 th day $(\mathrm{p}<0.05)$.

Conclusion: Hydrogel preparation in group 6 has the most potential in healing excision wounds.
\end{abstract}

Keywords: Kirinyu leaf, collagen, hydrogel, excision wound.

A R T I C L E I N F 0: Received 25 Nov 2019; $\quad$ Review Completed 13 Jan 2020； $\quad$ Accepted 25 Jan 2020; Available online 15 Feb . 2020

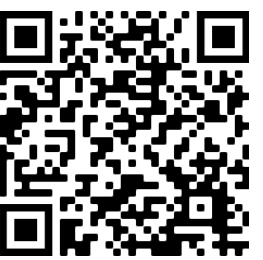

Cite this article as:

Thursina C. S. ${ }^{*}$, Reveny J., Sumaiyah S, Hydrogel Activity Test from Kirinyu Leaf Ethanol Extract (Chromolaenaodorata (L.) R. King \& H. Rob) and Combination of Kirinyu Leaf Ethanol Extract with Collagen As A Healing Wound Excision., Asian Journal of Pharmaceutical Research and Development. 2020; 8(1):35-37.

DOI: http://dx.doi.org/10.22270/ajprd.v8i1.651

Thursina, C. S.*, Department of Pharmaceutical Technology, Faculty of Pharmacy, Universitas Sumatera Utara, Medan, Indonesia.

\section{INTRODUCTION}

$\mathrm{I}$ njury is a disorder or damage from the integrity of the skin. One type of wound is an excision wound, which is the loss of skin as a whole and is widespread, causing a large amount of tissue to be lost ${ }^{1}$. Kirinyu leaves contain several main compounds such as tannins, phenols, flavonoids, saponins and steroids. Tannins and flavonoids are one of the compounds contained in the leaves of Kirinyu which can accelerate the process of wound healing due to its efficacy as an astringent, which has a role in shrinking wounds and increasing the rate of epithelialization. Flavonoids and saponins also have the ability as a cleanser and antiseptic that functions to kill or prevent the growth of microorganisms that commonly occur in wounds so that the wound does not experience severe infections ${ }^{2-3}$. Collagen is a fibrous protein that gives strength and flexibility to tissues and bones and plays an important role for other tissues, including the skin and tendons. This compound is the main protein that makes up the extracellular matrix component ${ }^{4}$.

Hydrogels are semisolid preparations formed by hydrophilic tissue. Hydrogel is ideally used as a wound cover material because it can help remove dead tissue. Hydrogels are able to absorb water or biological fluids so that the wound area becomes dry and is able to provide a cold feeling to the skin caused by the slow evaporation of water so as to reduce swelling around the wound so that it will speed up the wound healing process ${ }^{5-6}$.

\section{MATERIALS AND METHODS}

\section{Plant and Chemical Material}

Kirinyu leaves were obtained from Aceh (Indonesia), Collagen, Ethanol, Carbopol 940, Na-CMC, Propylen glycol, Triethanolamine, Glycerin, Distilled Water. 


\section{Preparation of Extracts}

Making extracts is done by maceration. $500 \mathrm{~g}$ of simplicia powder soaked with $70 \%$ alcohol for 6 hours while stirring occasionally. Then let stand for 18 hours. Separate maserat by filtering. Repeat the search process twice with the same type and amount of solvent. Furthermore, all maserates are collected, then evaporated with a rotary evaporator at $\pm 50^{\circ} \mathrm{C}$ until a thick extract is obtained.

\section{Formulation of Hydrogel}

The process of making hydrogel begins with the development of carbopol and Na-CMC in $20 \mathrm{ml}$ distilled water. then stir until homogeneous. Add glycerin and propylenglycol and complete triethanolamine while stirring constantly and add distilled water. Then add thick extract with various concentrations that have been dissolved into $2 \mathrm{ml}$ of distilled water to produce hydrogel ethanolic extract of kirinyu leaf and add ethanol extract of kirinyu leaf and collagen powder which has been dissolved into $1 \mathrm{ml}$ of $0.5 \mathrm{M}$ acetic acid to produce hydrogel ethanol extract Kirinyu leaf combination with collagen. The percentage of the ingredients of hydrogel formula (Table 1) was modified from the hydrogel formula which was carried out in the previous study by Edy, et $\mathrm{al}^{6}$.

Table 1: Hydrogel formulation of kirinyu leaf ethanol extract and combination of kirinyu leaf ethanol extract with collagen.

\begin{tabular}{|l|l|l|l|l|l|}
\hline \multirow{2}{*}{ Composition of Hydrogel } & \multicolumn{4}{l}{ Formulation (\%) } & F1K \\
\cline { 2 - 6 } & F0 & F1 & F2 & F1K & F2K \\
\hline Extract & - & 3 & 5 & 3 & 5 \\
\hline Collagen & - & - & - & 1 & 1 \\
\hline Carbopol 940 & 1 & 1 & 1 & 1 & 1 \\
\hline Na-CMC & 1 & 1 & 1 & 1 & 1 \\
\hline Propylen glycol & 2 & 2 & 2 & 2 & 2 \\
\hline Triethanolamine & 1 & 1 & 1 & 1 & 1 \\
\hline Glycerin & 12,5 & 12,5 & 12,5 & 12,5 & 12,5 \\
\hline Distilled Water ad & 100 & 100 & 100 & 100 & 100 \\
\hline
\end{tabular}

\section{Physical Evaluation of Hydrogel}

Physical evaluation of the preparation includes organoleptic, homogeneity, $\mathrm{pH}$ measurement and viscosity of the preparation. Stability test is carried out for 90 days.

\section{Experimental Animal}

The experimental animals used in this study were male Wistar strain rats (Rattus Norvegicus) weighing 200-250 g. The experimental protocol was approved by the Institutional Animal Ethics Committee.

\section{Wound Making for Test Animals}

The rats were acclimatized for 7 days, then anesthetized using ketamine $\mathrm{HCl}$, then the hair was shaved on the back of the rat to be made wound then cleaned with cotton that was given $70 \%$ alcohol. The wound pattern is made in a circle with a $20 \mathrm{~mm}$ diameter. Then made a wound with the size of a sign that has been made in the form of a circle on the back by lifting the skin of test animals with tweezers then cut with surgical scissors ${ }^{7}$. Mice will be divided into 6 groups, namely group 1 treated with a hydrogel base, group 2 treated with Octenilin ${ }^{\circledR}$ gel , group 3 treated with Kirinyu leaf ethanol extract hydrogel 3\%, group 4 treated with Kirinyu leaf ethanol extract hydrogel, group 5 treated with Kirinyu leaf ethanol extract hydrogel

Table 2: The results of $\mathrm{pH}$ measurements of hydrogel
$3 \%$ combination of $1 \%$ collagen combination and group 6 treated with Kirinyu leaf ethanol extract hydrogel $5 \%$ combination of $1 \%$ collagen.

\section{RESULTS AND DISCUSSION}

\section{Organoleptic test}

Organoleptic examination results of hydrogel preparations are form and consistency which is updated for 90 days. Hydrogel preparations of Kirinyu leaf ethanol extract combined with collagen produce a brown color and a characteristic smell of Kirinyu leaves.

\section{Homogeneity test}

Homogeneity examination showed that all preparations were homogeneous.

\section{pH measurement}

The $\mathrm{pH}$ determination of the hydrogel preparation is carried out using a $\mathrm{pH}$ meter for 90 days. The differences in the $\mathrm{pH}$ of the preparations are caused by differences in the concentration of the Kirinyu leaf extract contained in the formula. The $\mathrm{pH}$ criteria for skin preparations are at a $\mathrm{pH}$ interval of $4.5-6.5^{8}$. Table 2 shows the results of the $\mathrm{pH}$ values from the four formulas for 90 days at room temperature.

\begin{tabular}{|l|l|l|l|l|l|l|}
\hline \multirow{2}{*}{ Formulation } & \multicolumn{6}{|l|}{$\mathrm{pH}$} \\
\cline { 2 - 7 } & 0 Days & 7 Days & 14 Days & 21 Days & 28 Days & 90 Days \\
\hline F0 & 6,3 & 6,3 & 6,3 & 6,3 & 6,3 & 6,3 \\
\hline F1 & 6,3 & 6,3 & 6,3 & 6,3 & 6,2 & 5,9 \\
\hline F2 & 6,1 & 6,1 & 6,1 & 6,1 & 6,0 & 5,4 \\
\hline F1K & 5,8 & 5,8 & 5,8 & 5,8 & 5,7 & 5,3 \\
\hline F2K & 5,7 & 5,7 & 5,7 & 5,7 & 5,5 & 4,8 \\
\hline
\end{tabular}




\section{Viscosity test}

The results of determining the hydrogel viscosity were carried out using a NDJ-8S viscometer on all preparations. Viscosity testing aims to determine the viscosity value of a substance. Good viscosity of hydrogel preparation is 50$150 \mathrm{dPa}^{9} \mathrm{~s}^{9}$. Table 3 shows the results of the viscosity values of the four formulas for 90 days at room temperature.

Table 3: The results of viscosity measurements of hydrogel

\begin{tabular}{|l|l|l|l|l|l|l|}
\hline \multirow{2}{*}{ Formulation } & \multicolumn{5}{|l}{ Viscosity (dPa.s) } \\
\cline { 2 - 7 } & 0 Days & 7 Days & 14 Days & 21 Days & 28 Days & 90 Days \\
\hline F0 & 99,9 & 99,9 & 99,9 & 99,9 & 99,9 & 99,9 \\
\hline F1 & 99,9 & 99,9 & 99,9 & 99,9 & 99,9 & 99,9 \\
\hline F2 & 99,9 & 99,9 & 99,9 & 99,9 & 95,1 & 70,8 \\
\hline F1K & 99,9 & 99,9 & 99,9 & 99,9 & 99,9 & 70,2 \\
\hline F2K & 99,9 & 99,9 & 99,9 & 96,4 & 85,3 & 63,4 \\
\hline
\end{tabular}

\section{Percentage of wound diameter reduction}

Test results on excision wound testing were analyzed using the SPSS program 25, One Way ANOVA method. Group 1 shows the percentage of wound diameter shrinkage of $100 \%$ on the $28^{\text {th }}$ day. Group 2 shows the percentage of wound diameter shrinkage of $100 \%$ on the $16^{\text {th }}$ day. Groups 4, 5 and 6 show the percentage of wound diameter shrinkage of $100 \%$ on the $18^{\text {th }}$ day. In group 3 the percentage diameter of $100 \%$ shrinkage on the $21 \mathrm{st}$ day on the new graph is seen on the 22nd day.

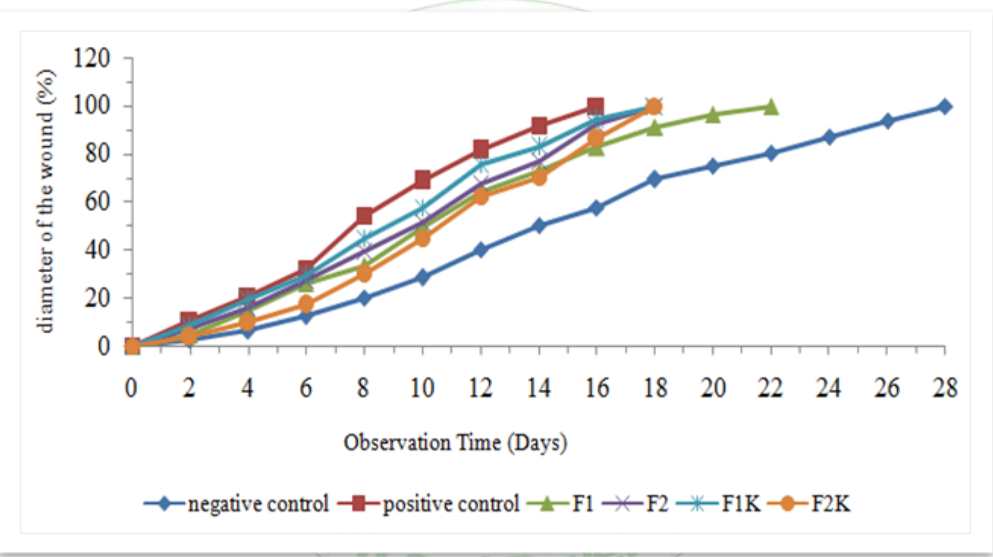

Figure 1: Graph of percentage reduction in wound diameter in each group observed on the day of observation

The results of statistical analysis showed that the group given hydrogel ethanol extract of kirinyu leaf gave a significant

difference compared to the group given hydrogel without ethanol extract of kirinyu leaf which began to be seen on the 10th day ( $\mathrm{p}<0.05)$. The group that was given hydrogel ethanol extract of kirinyu leaf with collagen also gave a significant difference with the group that was given hydrogel without ethanol extract of kirinyu leaf which began to be seen on the 8 th day $(\mathrm{p}<0.05)$.

\section{CONCLUSION}

Hydrogel preparation of 5\% kirinyu leaf ethanol extract with the addition of $1 \%$ collagen has the greatest potential in wound healing.

\section{ACKNOWLEDGMENTS}

This research was facilitated by the Faculty of the Pharmacy University of Sumatera Utara in 2019.

\section{REFERENCES}

1. Arisanty, I.P. Konsep Dasar Manajemen Perawatan Luka. Jakarta: Penerbit Buku Kedokteran EGC. 2013; 2:29-37.

2. Barku, V.Y.A., Boye, A., and Ayaba, S. Phytochemical Screening and Assessment of Wound Healing Activity of The Leaves of Anogeissus leiocarpus. European Journal of Experimental Biology. 2013; 3(4): 18-25.

3. Yenti, R., Afrianti R., dan Sandi, M. Uji Efektivitas Krim Ekstrak Etanol Euphatorium odoratum (L) Terhadap Kerapatan Serabut Kolagen Pada Proses Penyembuhan Luka. SCIENTIA. 2013; 3(1):1116.

4. Fratzl, P. Collagen: Structure and Mechanics. New York: Springer. 2008; 1-13.

5. Voigt, R. Buku Pelajaran Teknologi Farmasi. Penerjemah: Soendani Noerono S. Yogyakarta: UGM Press. 1995; 568.

6. Edy, H.J., Marchaban, Wahyuono, S., and Nugroho, A.E. Formulation and Evaluation of Hydrogel Containing Tagetes Erecta (L) Leaves Etanolic Extract. International Journal of Current Innovation Research. 2017; 3(3):627-630.

7. Putra, D.A.C., Lutfiyati, H., dan Pribadi, P. Efektifitas Gel Ekstrak Daun Pisang (Musa paradisiaca L.) Untuk Penyembuhan Luka. Pharmaciana. 2017; 7(2):177-184.

8. Rahmayanti, A. Ekstraksi Kolagen Dari Kulit Ikan Gabus (Channa striata) Serta Aplikasinya Untuk Skrining Dan Karakterisasi Kolagenase Bakteri Asal Indonesia. Tesis. Sekolah Pascasarjana Institut Pertanian Bogor. 2014; 1.

9. Yuliani, N.S. Efek Ekstrak Etanol Daun (Chromolaena odorata) Terhadap Kesembuhan Luka Insisi pada Tikus Sprague Dawley. Tesis. Yogyakarta: Program Studi Sain Veteriner. Universitas Gadjah Mada. 2012; 8-10:43. 